\title{
EFEK PENINGKATAN SERAT KASAR DENGAN PENGGUNAAN DAUN MURBEI DALAM RANSUM BROILER TERHADAP PERSENTASE BOBOT SALURAN PENCERNAAN
}

\author{
Hamdan Has*, Astriana Napirah dan Amiluddin Indi \\ Fakultas Peternakan Universitas Halu Oleo Kendari \\ has.hamdan@yahoo.co.id*
}

\begin{abstract}
ABSTRAK
Penelitian ini bertujuan untuk mengetahui pengaruh peningkatan serat kasar dengan penggunaan daun murbei terhadap persentase bobot saluran pencernaan broiler. Seratus ekor DOC (day old chick) broiler, daun murbei, cairan rumen dan bahan pakan lainnyadigunakan dalam penelitian dengan rancangan acak lengkap 5 perlakuan yaitu T0 (kontol), T1 (penggunaan $10 \%$ daun murbei), T2 (10\% daun murbei fermentasi), T3 (20\% daun murbei) dan T4 (20\% daun murbei fermentasi) serta 4 ulangan. Parameter yang diamati berupa persentase bobot saluran pencernaan (tembolok, proventrikulus, gizzard, hati, pangkreas, usus halus, sekum). Hasil penelitian menunjukan peningkatan serat kasar dengan $10 \%$ dan $20 \%$ daun murbei (fermentasi dan tidak fermentasi) tidak berpengaruh nyata $(\mathrm{P}>0,05)$ terhadap bobot tembolok, proventiculus, hati dan pangkreas. Tetapi berpengaruh nyata $(\mathrm{P}<0,05)$ meningkatkan bobot gizzard pada taraf $20 \%$ murbei dibanding kontrol, perlakuan $10 \%$ dan $20 \%$ berpengaruh nyata $(\mathrm{P}<0,05)$ meningkatkan bobot usus halus (doudenum, jejenum, ileum) dan sekum dibanding kontrol. Perlakuan fermentasi dan tanpa fermentasi tidak menunjukan perbedaan untuk semua parameter. Peningkatan serat kasar ransum dapat mempengaruhi bobot saluran pencernaan terutama gizzard, usus halus dan sekum.
\end{abstract}

Kata kunci: Serat Kasar, Daun Murbei, Saluran Pencernaan

\begin{abstract}
This study conducted to determine the effect of increasing crude fiber by using murlberry leaf on weight percentage of broiler digestive tract. One hundred DOC (day old chick) broilers, mulberry leaf, rumen fluid and other feed ingredients used in a completely randomized design research with 5 treatment T0 (control), T1 (10\% mulberry leaves), T2 (10\% fermented mulberry leaves), T3 (20\% mulberry leaves) and T4 (20\% fermented mulberry leaf) and 4 replications. Parameters observed was weight percentge of gastrointestinal tract (crop, proventriculus, gizzard, liver, pancreas, small intestine, cecum). The results showed the increasing crude fiber with $10 \%$ and $20 \%$ mulberry leaves (fermented and not fermented) were not significant $(\mathrm{P}>0.05)$ on crop, proventiculus, liver and pancreas, but significant $(\mathrm{P}<0.05)$ increase gizzard weight at $20 \%$ murlberry compared to control, treatment $10 \%$ and $20 \%$ murlberry increase significantly $(\mathrm{P}<0.05)$ weight of the small intestine (doudenum, jejenum, ileum) and ceca compared control. Fermented and unfermented treatment showed no difference for all parameters. The increase in crude fiber diet can affect the digestive tract, especially the weight of gizzard, small intestine and cecum.
\end{abstract}

Keyword: Crude Fiber, Murlberry Leaf, Digestive Tract 


\section{PENDAHULUAN}

Tingkat serat kasar dalam ransum sangat berpengaruh terhadap performa dan pertumbuhan ternak (Anaoegwa dkk., 1989; Varastegani dan Dahlan, 2014). Serat kasar dibutuhkan ternak untuk merangsang gerakan saluran pencernaan, pada ternak ruminansia serat kasar digunakan sebagai sumber energi tetapi pada unggas pemanfaatannya sangat terbatas. Kekurangan serat pada pakan unggas dapat menyebabkan gangguan pencernaan, tetapi jumlah serat kasar berlebihan juga dapat menurunkan kecernaan pakan.

Kebutuhan serat pakan pada beberapa jenis unggas berbeda-beda tergantung jenisnya, puyuh maksimal 7\%, itik maksimal $8 \%$ sedangkan ayam pedaging maksimal 6\% (SNI, 2006). Banyak penelitian yang telah dilakukan untuk menggambarkan peranan serat kasar dalam ransum terhadap unggas, seperti efek toksikologi, efek probiotik dan efesiensi pakan. Unggas khususnya broiler memiliki kemampuan yang rendah dalam memanfaatkan serat kasar tetapi tetap membutuhkannya dalam jumlah kecil serta dapat mempengaruhi histologi saluran pencernaan (Tossaporn, 2013).

Daun murbei merupakan pakan lokal yang memiliki kandungan nutrisi yang baik dengan protein kasar 23\% (Mirnawati et al., 2013), sehingga berpotensi digunakan sebagai pakan unggas, tetapi kandungan serat kasar daun murbei cukup tinggi berkisar 25\% (Has, 2013) sehingga dapat membatasi penggunaannya sebagai pakan unggas. Fermentasi dapat meningkatkan penggunaan daun murbei dengan cara meningkatkan kecernaan nutrisi dalam tubuh (Has dkk., 2013; Mirnawati dkk., 2013).

Peningkatan serat dalam pakan unggas diduga berbanding terbalik dengan kecernaan pakan. Organ saluran pencernaan memiliki peranan yang sangat penting terhadap kecernaan bahan pakan, morfologi saluran pencernaan merepresentasikan kondisi ternak dan kemampuan pencernaan. Jenis serat dan sumber serat pada ransum unggas akan berdampak pada performa dan perubahan morfologi organ dalam terutama saluran pencernaan (Iyayi dkk., 2005). Salah satu metode yang digunakan untuk mengetahui kondisi saluran pencernaan adalah dengan pengukuran berat relatif. Hal ini yang mendasari dilaksanakan penelitian efek peningkatan serat kasar terhadap morfologi organ pencernaan melalui pengukuran berat relatif.

\section{MATERI DAN METODE}

Seratus ekor day old chick (DOC) strain CP 707 dipelihara menggunakan kandang litter tipe koloni kapasitas 5-8 ekor. Bahan yang digunakan adalah daun murbei (Morus Alba) berumur 90 hari, starter cairan rumen, jagung, bungkil kedelai, PMM, bekatul, tepung ikan, polard, minyak dan mineral mix. Daun murbei yang digunakan terlebih dahulu dikeringkan dan dibuat tepung, setelah itu dicampur dengan starter cairan rumen lalu difermentasi selama 2 minggu secara anaerob lalu dicampur ke dalam ransum.

Rancangan Acak Lengkap 5 perlakuan dan 4 ulangan digunakan sebagai rancangan penelitian, tiap ulangan terdiri atas 5 ekor ayam.

Perlakuan yang diberikan terdiri atas:

T0:tanpa penggunaan daun murbei (kontrol)

T1: $10 \%$ daun murbei

$\mathrm{T} 2: 10 \%$ daun murbei fermentasi

T3 : 20\% daun murbei

$\mathrm{T} 4: 20 \%$ daun murbei fermentasi

Pakan dan air minum diberikan secara ad libitum. Pakan disusun berdasarkan rekomendasi NRC (1994) dengan kandungan protein $22 \%$ dan energi metabolis $2900 \mathrm{kkal} / \mathrm{kg}$, dengan formulasi tercantum pada Tabel 1. Semua perlakuan 
diberi pakan yang sama pada umur 1-7 hari, umur 8-10 hari pakan perlakuan mulai diadaptasikan secara bertahap, pakan perlakuan diberikan secara penuh pada umur 11- 35 hari.

Pada hari ke 35 satu ekor ayam dari tiap unit perlakuan yang telah dipuasakan terlebih dahulu, diambil, ditimbang kemudian disembelih. Setelah itu dipisahkan organ dalamnya dari karkas, lalu tiap bagian saluran pencernaan dipisahkan, ditimbang dengan teliti serta diamati. Semua proses pemisahan, penimbangan dan pengamatan dilakukan pada hari dan orang yang sama untuk meminimalkan bias. Parameter penelitian adalah bobot organ saluran pencernaan meliputi (tembolok, venticulus, gizzard, pangkreas, hati, usus halus, usus besar, usus buntu). Pengukuran bobot dilakukan dengan menggunakan timbangan analitik kemudian persentase dihitung berdasarkan bobot hidup.

Data yang diperoleh dianalisis dengan menggunakan analisis variansi Rancangan Acak Lengkap dan akan dilanjutkan dengan uji Duncan's New Multiple Range Test (Gaspersz, 1991) untuk uji beda antar perlakuan.

\section{HASIL DAN PEMBAHASAN}

Penggunaan daun murbei dalam ransum meningkatkan kandungan serat kasar ransum secara keseluruhan, semakin tinggi penggunaan daun murbei semakin tinggi peningkatan total serat kasar ransum (Tabel 1). Daun murbei merupakan pakanberbasis hijauan yang mengandung serat kasar tinggi

Tabel 1. Komposisi ransum dan kandungan nutrisi pakan perlakuan

\begin{tabular}{llllll}
\hline \multirow{2}{*}{ Bahan } & \multicolumn{7}{l}{ Perlakuan $(\%$ bahan kering) } & \\
\cline { 2 - 5 } Jontrol & $\mathrm{T} 1$ & $\mathrm{~T} 2$ & $\mathrm{~T} 3$ & $\mathrm{~T} 4$ \\
Bekatul & 55 & 51 & 51 & 48 & 48 \\
Bungkil kedelai & 14 & 13 & 13 & 3 & 3 \\
Pollard & 10 & 6 & 6 & 10 & 10 \\
Tepung ikan & 12 & 12 & 12 & 4 & 4 \\
PMM & 2 & 2 & 2 & 12 & 12 \\
Minyak nabati & 1 & 1 & 1 & 2 & 2 \\
Daun murbei & 0 & 10 & 10 & 1 & 1 \\
Total & 100 & 100 & 100 & 20 & 20 \\
Kandungan nutrisi & & & & 100 & 100 \\
Protein kasar(\%) & 22,01 & 22,02 & 22,22 & 22,01 & 22,43 \\
Lemak kasar(\%) & 4,19 & 4,17 & 4,17 & 4,07 & 4,07 \\
Serat kasar(\%) & 5,6 & 7,2 & 6,8 & 8,9 & 8,1 \\
Energi metabolis & & & & & \\
(Kcal/kg) & 2930 & 2909 & 2908 & 2926 & 2922 \\
Lycin & 1 & 1,1 & 1,18 & 1,1 & 1,2 \\
Methionin & 0,42 & 0,44 & 0,48 & 0,46 & 0,5 \\
\hline
\end{tabular}


sehingga penggunaaannya akan meningkatkan serat kasar ransum (Ani et al., 2012). Gonzalez (2007); Hetland dan Svihus (2001) melaporkan bahwa serat berperan penting dalam perubahan morfologi dan histologi saluran pencernaan.

\section{Tembolok, Proventriculus, Gizzard}

Persentase tembolok dan proventriculus tidak menunjukan perbedaan nyata akibat penggunaan daun murbei dalam ransum, hal ini menunjukan peningkatan serat kasar masih dapat ditolerir oleh beban kerja dari tembolok dan gizzard. Jamal (2005), melaporkan tidak ada perbedaan bobot oeshopagus, proventiculus dan tembolok pada broiler yang mengkonsumsi pakan berserat dari ampas saitun, hal serupa dilaporkan Tossaporn (2013), yang menyatakan tidak ada pengaruh perbedaan serat kasar terhadap tembolok dan proventikulus. Bobot tembolok dan proventrikulus dalam penelitian ini masih tergolong normal, Ukim dkk. (2012), menyatakan persentase bobot proventiculus broiler normal berkisar antara 0,4-0,54\% dari bobot hidup. Peran tembolok pada broiler adalah sebagai penampung makanan sebelum dicerna oleh gizzard, sedangkan pada broiler peran organ ini kurang berkembang karena prilaku broiler yang makan terus menerus sehingga tidak perlu menampung makanan dalam jumlah banyak. Fungsi dari proventriculus adalah sebagai pencerna kimiawi dan gerbang pakan sebelum masuk ke gizard sehingga perubahan serat diduga tidak terlalu berpengaruh.

Persentase bobot gizzard pada penelitian ini antara 1,82-2,22 \%, masih sesuai dengan yang dilaporkan oleh Ukim dkk. (2012) yang berkisar antara 2,07-2,31 $\%$ tetapi masih lebih tinggi dibanding Hernandez dkk. (2004); Huang dkk. (2009), berkisar 1,35-1,41. Hasil penelitian ini menunjukan terdapat perbedaan nyata pada persentase bobot gizzard akibat penggunaan daun murbei terutama pada perlakuan $20 \%$ murbei dibanding kontrol. Hal ini disebabkan peningkatan serat kasar ransum yang memicu perkembangan gizzard. Hal serupa dilaporkan Chinajariyawong dan Muangkeow(2011) yang menyatakan

Tabel 2. Pengaruh peningkatan serat kasar dengan penggunaan daun murbei terhadap persentase bobot organ saluran pencernaan

\begin{tabular}{llllll}
\hline parameter & kontrol & T1 & T2 & T3 & T4 \\
\hline Tembolok & $0,53 \pm 0,04$ & $0,46 \pm 0,19$ & $0,50 \pm 0,09$ & $0,43 \pm 0,05$ & $0,50 \pm 0,09$ \\
Proventriculus & $0,48 \pm 0,05$ & $0,48 \pm 0,05$ & $0,51 \pm 0,1$ & $0,55 \pm 0,04$ & $0,59 \pm 0,09$ \\
Gizzard & $1,85 \pm 0,13^{\text {ab }}$ & $1,84 \pm 0,09^{\text {ab }}$ & $1,82 \pm 0,1^{\mathrm{a}}$ & $2,1 \pm 0,18^{\mathrm{bc}}$ & $2,22 \pm 0,24^{\mathrm{c}}$ \\
Hati & $2,27 \pm 0,35$ & $2,32 \pm 0,36$ & $2,38 \pm 0,51$ & $2,13 \pm 0,17$ & $2,15 \pm 0,17$ \\
Pangkreas & $0,23 \pm 0,05$ & $0,22 \pm 0,02$ & $0,23 \pm 0,05$ & $0,24 \pm 0,04$ & $0,25 \pm 0,04$ \\
Doudenum & $0,5 \pm 0,06^{\mathrm{a}}$ & $0,57 \pm 0,08^{\mathrm{ab}}$ & $0,61 \pm 0,03^{\mathrm{bc}}$ & $0,68 \pm 0,06^{\mathrm{cd}}$ & $0,73 \pm 0,01^{\mathrm{d}}$ \\
Jejenum & $1,24 \pm 0,04^{\mathrm{a}}$ & $1,45 \pm 0,13^{\mathrm{b}}$ & $1,41 \pm 0,16^{\mathrm{ab}}$ & $1,47 \pm 0,05^{\mathrm{b}}$ & $1,51 \pm 0,13^{\mathrm{b}}$ \\
Ileum & $0,96 \pm 0,14^{\mathrm{a}}$ & $1,28 \pm 0,04^{\mathrm{b}}$ & $1,20 \pm 0,13^{\mathrm{b}}$ & $1,32 \pm 0,04^{\mathrm{b}}$ & $1,32 \pm 0,19^{\mathrm{b}}$ \\
Sekum & $0,58 \pm 0,02^{\mathrm{a}}$ & $0,67 \pm 0,04^{\mathrm{b}}$ & $0,68 \pm 0,02^{\mathrm{b}}$ & $0,73 \pm 0,03^{\mathrm{c}}$ & $0,71 \pm 0,03^{\mathrm{bc}}$ \\
\hline
\end{tabular}

Superskrip berbeda pada baris yang sama menunjukan perbedaan nyata $(\mathrm{P}<0,05)$. 
terjadi peningkatan bobot gizard seiring peningkatan serat kasar. Hetland dkk. (2005)melaporkan terjadi peningkatan bobot gizzard ayam petelur yang mendapat akses mengkonsumsi sekam kayu, ayam petelur yang mengkonsumsi pakan mengandung 4\% sekam kayu memililki bobot gizzard yang lebih tinggi dibanding kontrol.

Gizzard merupakan alat pencernaan yang berperan sebagai pencerna mekanik sehingga tekstur ransum yang lebih keras akibat serat kasar tinggi dapat memicu pertumbuhan gizzard. Perlakuan fermentasi pada daun murbei tidak menunjukan perbedaan nyata terhadap bobot gizzard hal ini diduga karena fermentasi hanya merubah ikatan dan merenggangkan ikatan senyawa daun murbei tetapi tidak merubah tekstur dan ukurannya. Bentuk dan serat kasar pakan merupakan faktor utama yang dapat mempengaruhi bobot gizzard (Hetland dkk., 2005)

\section{Hati dan pangkreas}

Persentase bobot hati pada penelitian ini 2,13 - 2,38 \% dari bobot hidup. Hasil ini tidak berbeda jauh dengan Tossaporn (2013) yang melaporkan bobot hati berkisar 2,32\% - 2,67\% dari bobot hidup, tetapi lebih rendah dariRetnani (2009) yang berkisar antara 2,7-2,9 \% dari bobot hidup. Hasil penelitian ini menunjukan tidak ada perbedaan nyata terhadap persentase bobot hati dan pangkreas. Tossaporn (2013) melaporkan bobot hati berkisar $2,32 \%-2,67 \%$ dari bobot hidup dan tidak dipengaruhi oleh perubahan serat kasar ransum.

Peranan hati adalah pusat metabolisme zat dan penawar racun sedangkan pangkreas bekerja dalam menghasilkan enzym pencernaan. Peningkatan serat dan penggunaan daun murbei diduga tidak menyebabkan kelainan terhadap metabolisme dan tidak menimbulkan keracunan sehingga tidak berpengaruh terhadap fungsi hati dan pangkreas. Hal serupa dilaporkan oleh Jamal (2005), yang mengemukakan bahwa peningkatan jumlah serat akibat penggunaan bungkil saitun tidak berpengaruh terhadap hati dan jantung. Hal ini tidak sesuai dengan Hatta (2009), yang menyatakan peningkatan serat kasar ransum berpengaruh nyata terhadap bobot relatif hati dan pangkreas.

\section{Doudenum, Jejenum dan Ileum}

Persentase bobot usus halus secara keseluruhan pada penelitian ini masih lebih tinggi dari yang dilaporkan Nurhayati (2010) yang berkisar antara 1,7 -2,03\%. Hasil penelitian menunjukan terdapat perbedaan persentase bobot organ usus halus jika dibanding dengan kontrol, penggunaan daun murbei $10 \%$ dan $20 \%$ nyata $(\mathrm{P}<0,05)$ meningkatkan bobot usus halus secara keseluruhan (doudenum, jejenum, ileum) semakin tinggi tingkat serat kasar ransum semakin tinggi bobot usus halus. Iyayi dkk (2005) melaporkan Penggunaan pakan berserat tinggi dalam ransum secara nyata menurunkan performa, meningkatkan bobot gizzard, sekum dan usus halus.

Penggunaan daun murbei dalam ransum menurunkan kecernaan khususnya protein dan energi (Mirnawati dkk., 2013), hal ini menyebabkan kerja usus halus menjadi lebih berat untuk memaksimalkan pencernaan. Pakan berserat yang mengandung NSP tinggi dapat menurunkan kecernaan pakan dan membebani kerja usus halus khususnya ileum (Syarifi dkk., 2012). Ronald (1984)menambahkan perkembangan saluran intestinal atau usus halus sangat dipengaruhi oleh kesempatan makan, aliran digesta serta pengaruh serat. Pengaruh fermentasi pada daun murbei 
masih tidak tampak baik pada perlakuan 10 $\%$ atau $20 \%$ daun murbei. Hal ini diduga karena kecernaan di usus halus baik untuk pakan fermentasi atau tidak tidak berbeda.

\section{Sekum (usus buntu)}

Persentase bobot sekum pada penelitian ini berkisar antara $0,58-0,73 \%$, hasil ini lebih tinggi dari yang dilaporkan Tossaporn (2013), yaitu 0,46-0,49\%, tetapi lebih rendah dari Syarifi dkk. (2012) antara 0,65-0,85 \% dari bobot hidup. Hasil penelitian menunjukan perbedaan nyata $(\mathrm{P}<0,05)$ antara perlakuan, perlakuan $10 \%$ murbei memiliki bobot sekum yang lebih tinggi dibanding kontrol dan semakin meningkat pada penggunaan $20 \%$ murbei. Hal ini menunjukan peningkatan serat berpengaruh terhadap fungsi sekum.

Sekum merupakan saluran pencernaan yang berfungsi sebagai tempat pencernaan secara mikrobial dengan tujuan untuk mencerna nutrien yang tidak terserap di usus halus khususnya serat dan nitrogen, ternak non ruminan yang mengalami perkembangan sekum memiliki kemampuan memanfaatkan serat lebih baik (Varastegani dan Dahlan, 2014). Peningkatan bobot sekum disebabkan peningkatan aktivitas pencernaan nutrisi yang tidak terserap di usus halus sebagai dampak berkuranggnya kecernaan pakan di usus (Syarifi dkk., 2012).

\section{KESIMPULAN}

Penelitian ini menggambarkan pengaruh serat kasar terhadap bobot organ saluran pencernaan yang sangat berkaitan dengan tingkat kecernaan ransum. Serat kasar yang tinggi memicu organ organ saluran pencernaan bekerja lebih berat sehingga terjadi perubahan morfologi yang ditandai dengan peningkatan ukuran. Perlakuan fermentasi terhadap daun murbei tidak menunjukan pengaruh terhadap bobot saluran pencernaan.

\section{DAFTAR PUSTAKA}

Chinajariyawong, Charurat and Niwat Muangkeow. 2011. Carcass yield and visceral organs of broiler chickens fed palm kernel meal or Aspergillus wentii TISTR 3075 fermented palm kernel meal. Walailak J. Sci. \& Tech., 8(2): 175-185.

Friday O. L Anaoegwa, V.H. Varel, J.S. Dickson, W.G. Pond And L. Krook. 1989. Effects of dietary fiber and protein concentration on growth, feed efficiency, visceral organ weights and large intestine microbial populations of swine.J. Nutr. 119: 879-886.

Gonzalez A, J.M., E. Jimenez-Moreno, R. Lazaro and G.G. Mateos, 2007. Effect of type of cereal, heat processing of the cereal and inclusion of fiber in the diet on productive performance and digestive traits of broilers. Poultry Sci., 86: 1705-1715

Hernandez F., J. Madrid, V. Farcia, J. Orengo and M.D. Megias. 2004. Influence of two plant extracts on broilers performance, digestibility, and digestive organ size. Poultry Sci.,83:169-74.

Hetland H. and B. Svihus, 2001. Effect of oat hulls on performance, gut capacity and feed passage time in broiler chickens. Br. Poultry Sci., 42: 354-361.

Hetland H., B. Svihus and M. Choct. 2005. Role of insoluble fiber on gizzard activity in layers. J. Appl. Poult. Res., 14: 38-46.

Huang Y., J.S. Yoo, H.J. Kim, Y. Wang, Y.J. Chen, J.H. Cho and I.H. Kim. 2009. Effect of bedding types and different nutrient densities on growth 
performance, visceral organ weight, and blood characteristics in broiler chickens. J. Appl. Poult. Res., 18: 1-7.

Iyayi E.A., O. Ogunsola and R. Ijaya. 2005. Effect of three sources of fibre and period of feeding on the performance, carcase measures, organs relative weight and meat quality in broilers. International Journal of Poultry Science, 4(9): 695700.

Jamal M. Abo Omar . 2005. Carcass composition and visceral organ mass of broiler chicks fed different levels of olive pulp. Journal of The Islamic University of Gaza 13 (2): 76-84.

Mirnawati, B. Sukamto, dan V. D. Yunianto. 2013. Kecernaan protein, retensi nitrogen dan massa proteindaging ayam broiler yang diberi ransum daun murbei (Morus alba L.) yang difermentasi dengan cairan rumen.JITP, 3(1): 25-32.

Onwudike O.C. 1986. Palm kernel meal as a feed for poultry replacement of groundnut cake by palm kernel meal in broiler diets. Anim. Feed Sci. Tech., 16;195-202.

Retnani Y., E. Suprapti, I. Firmansyah, L. Herawati dan R. Mutia .2009. Pengaruh penambahan zat pewarna dalam ransum ayam broiler terhadap penampilan, persentase berat bursa fabrisius, karkas dan organ dalam. J.Indon.Trop.Anim.Agric., 34 (2): 115-121.

Ronald D. Drobney. 1984. Effect of diet on visceral morphology of breeding wood ducks. The AUK, 101 :93-98.

Sharifi Seyed Davood, Farid Shariatmadari and Akbar Yaghobfar. 2012. Effects of inclusion of hull-less barley and enzyme supplementation of broiler diets on growth performance, nutrient digestion and dietary metabolisable energy content. Journal of Central European Agriculture, , 13(1), p.193207

Tossaporn Incharoen. 2013. Histological adaptations of the gastrointestinal tract of broilers fed diets containing insoluble fiber from rice hull meal . American Journal of Animal and Veterinary Sciences, 8(2): 79-88.

Ukim C.I., Ojewola G S. and Obun C.O., Ndelekwute E.N.2012. Performance and carcass and organ weights of broiler chicks fed graded levels of Acha grains (Digitaria exilis). Journal of Agriculture and Veterinary Science. Volume 1(2): 28-33.

Varastegani A. and Dahlan I. 2014.Influence of dietary fiber levels on feed utilization and growth performance in poultry.J Anim. Pro. Adv., 4(6): 422-429. 